\title{
Reuse of Treated Municipal Wastewater from Constructed Wetlands for Cut Flowers Irrigation in Aeroponic Cultivation*
}

\author{
Reutilización de aguas residuales municipales tratadas provenientes de \\ humedales construidos para riego de flores de corte en cultivo aeropónico
}

Submitted on: 03 May 2020 | Accepted on: 27 January 2020 | Published: October 13, 2020

\author{
Ismael Leonardo Vera-Puerto ${ }^{a}$ \\ Universidad Católica del Maule, Chile \\ ORCID: 0000-0002-6445-2896 \\ Jorge Leonardo Olave-Vera \\ Universidad Arturo Prat, Chile \\ ORCID: 0000-0002-1459-970X

\section{Sussy Tapia} \\ Instituto de Fomento Pesquero (IFOP), Chile \\ ORCID: 0000-0002-9668-9193 \\ Wladimir Antonio Chavez \\ Universidad Arturo Prat, Chile \\ ORCID: 0000-0002-3386-9891 \\ Carlos Arias \\ Aarhus University, Denmark \\ ORCID: 0000-0002-6628-7564 \\ * Research article \\ a Corresponding author. E-mail: ivera@ucm.cl \\ DOI: https://doi.org/10.11144/Javeriana.iued24.tmwr
}

\section{How to cite this article:}

I. L. Vera-Puerto, J. L. Olave-Vera, S. Tapia, W. A. Chavez, and C. Arias, "Reuse of Treated Municipal Wastewater from Constructed Wetlands for Cut Flowers Irrigation in Aeroponic Cultivation," Ing. Univ., vol. 24, 2020. https://doi.org/10.11144/Javeriana.iued24.tmwr 


\section{Abstract}

The aim of this work is to evaluate the reuse of municipal wastewaters treated through subsurface constructed wetlands (SS-CWs) as irrigation water in cut flower aeroponic cultivation under arid conditions. For this purpose, two experimental aeroponic cultivation systems were installed with the cut flower Lilium 'Tresor' planted and irrigated with SS-CWs treated water. The results showed that the quality of the SS-CWs wastewater has to be improved to be used in irrigation. Despite that, Lilium 'Tresor' grew under arid conditions with normal stem diameters and number of flowers but with heights under $0.65 \mathrm{~m}$, which would restrict their commercialization to local markets. Water electrical conductivity (> $2300 \mu \mathrm{s} / \mathrm{cm}$ ) and luminosity (> 120 klux) were factors that affected plant height. When compared to other cultivation systems, the aeroponic cultivation system used between $10 \%$ and $20 \%$ of the amount of water needed to produce Lilium 'Tresor.' Thus, this work showed the feasibility to produce cut flowers using an aeroponic cultivation system under arid conditions and irrigated with SS-CWs effluents. Likewise, it was detected that improvements to water quality and luminosity must be made for industrial scaling.

Keywords: Aeroponics, municipal wastewater, subsurface constructed wetland, cut flower, reuse.

\section{Resumen}

Este trabajo tuvo por objetivo evaluar la reutilización de aguas residuales municipales tratadas por humedales construidos subsuperficiales (HC-SSs), como agua de riego, en el cultivo aeropónico de flores de corte en condiciones áridas. Para esto, se instalaron dos unidades experimentales de cultivo aeropónicas plantadas con la flor de corte Lilium 'Tresor' e irrigadas con agua tratada por HC-SSs. Los resultados mostraron que la calidad del agua efluente a los HC-SSs debe ser mejorada para ser reutilizada en riego. Pese a esto, el Lilium 'Tresor' se desarrolló en condiciones áridas, con diámetros de tallo y cantidad de flores normales, pero por tener alturas bajo $0.65 \mathrm{~m}$, su comercialización estaría limitada a mercados nacionales. La conductividad eléctrica en el agua (> $2300 \mu \mathrm{s} / \mathrm{cm}$ ) y la luminosidad (>120 klux) fueron los factores que afectaron la altura. El cultivo aeropónico utilizó solo entre 10 y $20 \%$ del agua para producir Lilium 'Tresor' comparado con otros sistemas de cultivo. Así, este trabajo mostró la factibilidad de producir flores de corte en un sistema de cultivo aeropónico en condiciones áridas y regadas con efluentes de HC-SSs, detectando que para su escalamiento industrial se deben hacer mejoras en la calidad del agua y la luminosidad.

Palabras clave: aeroponía, agua residual municipal, humedal construido subsuperficial, flor de corte, reutilización. 


\section{Introduction}

In arid areas, such as the Atacama Desert, the low availability of water resources $(<1000$ $\mathrm{m}^{3} /$ inhabitant-year) is a problem that will tend to increase due to the effect of climate change [1]. For this reason, alternative water sources are needed. Among the different sources, the reuse of treated effluents from wastewater has been explored as an alternative under these and other climatic conditions [2], [3]. However, the total percentage of treated water reused in the Atacama Desert does not exceed $10 \%$ [4], [5], unlike other arid zones, where the percentage can exceed $70 \%$ [6].

The low percentage of wastewater treated and reused in the Atacama Desert can be explained by several reasons. First of all, the location of the largest urban centers (Arica, Iquique, Antofagasta, La Serena-Coquimbo) on the shores of the Pacific Ocean, and the decision of the country to use submarine outfalls as a wastewater disposal system [3], [5]. A second reason is the natural geological condition that causes the salt content in soil and water to have values of $26 \mathrm{dS} / \mathrm{m}$ and $2 \mathrm{dS} / \mathrm{m}$, respectively [2], [7]. The third reason is associated to ignorance and disinformation on the potential users and beneficiaries of reuse [5]. Finally, there is also an associated factor in the form of low treatment coverage in decentralized or rural areas, with no official figures for the Atacama Desert, but it is estimated that coverage at the country level in Chile, does not exceed $20 \%$ [4].

The need to use alternative technologies for wastewater treatment in decentralized or rural areas has been discussed as opposed to the use of highly mechanized technologies, given the operational problems they have presented [8], [9]. Among these alternative technologies for arid conditions, the Constructed Wetlands (CWs) of the subsurface type (horizontal and vertical) have been successfully applied, with removal efficiencies over $80 \%$ for Chemical Oxygen Demand (COD), Biological Oxygen Demand (BOD 5 ) and Total Suspended Solids (TSS) [10], [11]. However, under the new paradigm of sustainable sanitation, it becomes necessary to recover resources from water treatment while improving its quality, thereby implementing a new circular economy model in wastewater management [12], [13].

It is in this way that CWs can be used for this new model of circular economy, integrating ornamental plants during treatment, which in some cases contribute with by-products such as cut flowers. Among the ornamental plants that have been used in CWs are Zantedeschia aethopica, Canna spp., Pontederia sagitttata, Spathiphyllum wallisii, Heliconia spp., Iris spp., and Lilbappia violacea [14]-[17]. Furthermore, CWs have achieved the production of effluents that, together with disinfection processes, can be used in the irrigation of agricultural products under arid climatic conditions, contributing to both the reuse of effluents and the circular economy model [18]-[20]. Despite this benefit, the information on the integration of CWs and the use of the resulting effluents as irrigation water for the 
production of agricultural products is limited, and even more so in combination with soilless cultivation techniques, despite the fact that effluents from other types of wastewater treatment have been used in arid areas [21]-[23].

Thus, the reuse of effluents is an important element of the sustainable management of water resources in arid conditions and a relevant factor in the new circular economy model. It is for this reason that the reuse of effluents in the irrigation of agricultural products, such as the ones of floriculture, presents itself as an opportunity given that in economic terms the horticultural sector, which includes floriculture, has a world production valued at nearly 37,000 million euros and involves around 170,000 farmers [24].

Therefore, due to the aforementioned reasons, this work aimed to evaluate the reuse of municipal wastewater treated by means of subsurface constructed wetlands (SS-CWs), as irrigation water for the production of cut flowers in a soilless cultivation system such as aeroponics, on a laboratory scale, under arid climatic conditions. In this way, it is expected that the treatment of wastewater in decentralized or rural areas under these climatic conditions may include an alternative for the reuse and revaluation of its effluents.

\section{Materials and Methods}

\section{Experimental Design}

Two experimental units (EU), EU-1 and EU-2, were used. They were built with plastic tanks of $0.60 \mathrm{~m} \times 0.4 \mathrm{~m} \times 0.4 \mathrm{~m}$ (length $\mathrm{x}$ width $\mathrm{x}$ height). Eight aeroponic baskets were installed for each EU on top of EU-1 and EU-2. The aeroponic baskets are made of plastic and grooved with a total volume of $232.26 \mathrm{~cm}^{3}$, filled with Arlite (inert material) for the development of the root. Lilium 'Tresor' was selected as the cut flower because it has a commercial market and also, it has shown tolerance to irrigation with water with an electrical conductivity of up to $2.3 \mathrm{dS} / \mathrm{m}$ [25]. The experimental units were installed in the experimental station of the Center for Research and Development in Water Resources (CIDERH) in the city of Iquique, in the north of Chile, in the coastal Desert of Atacama, and separated from the outside only by an anti-aphid mesh and without temperature regulation. Figure 1 shows the configuration of the proposed aeroponic unit. 
Figure 1. View of the experimental unit used. Measures in meters. Not to scale

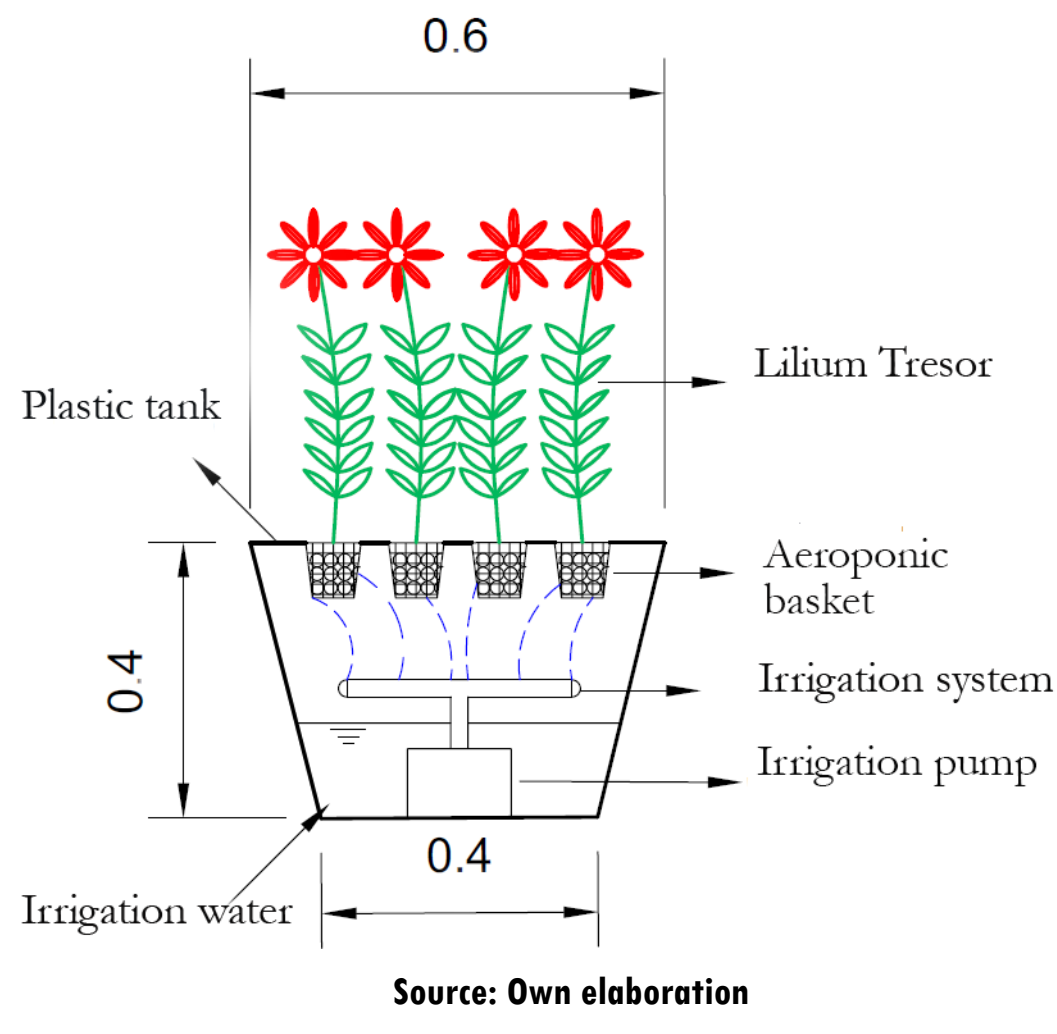

\section{Water Used for Irrigation}

Wastewater treated by means of SS-CWs was used as irrigation water. The CWs were fed with filtered wastewater $(10 \mathrm{~mm})$ from a nearby treatment plant. EU-1 was irrigated with water composed of an equivalent mixture $(50 \%)$ of effluents to two SS-CWs planted with Schoenoplectus americanus, operated in parallel, with two hydraulic retention times (HRT): $3.5 \mathrm{~d}$ and $7.5 \mathrm{~d}$. On the other hand, EU-2 was also irrigated by an equivalent mixture (50\%) of effluents from two SS-CWs, but in this case, planted with Cyperus papyrus, operated in parallel, with two HRTs: $3.5 \mathrm{~d}$ and $7.5 \mathrm{~d}$. The effluents used for irrigation were manually put in each EU. The effluents used correspond to months 4 to 7 of operation of the SSCWs. Further details on the CWs experimental system can be seen in Vera et al. [26].

\section{Operation and Monitoring Strategy}

The Lilium 'Tresor' flowers were planted in August 2014 and the systems were in operation for 9 weeks. Bulbs with a $12 \mathrm{~cm}$ to $14 \mathrm{~cm}$ circumference purchased from national producers were used for this purpose. The bulbs were disinfected to prevent fungus formation prior to planting. During plant growth, the height and diameter of the stem were manually measured every week for the 9 weeks of the experiment. The height was measured from the clay surface to the apex with a measuring tape. Diameter was measured at the midpoint of the 
plant height using a manual caliper. The harvest was made when $50 \%$ of the flower buds showed pigmentation. In the EU-1 and EU-2, irrigation water was manually changed every $7 \mathrm{~d}$, using $13 \mathrm{~L}$ for each change. The volume for the water change was defined according to the immersion condition required by the pump used for irrigation (figure 1). Prior to its use in irrigation, the effluent water from the SS-CWs was measured for Chemical Oxygen Demand (COD), Total Suspended Solids (TSS), Total Nitrogen (TN), Total Phosphorus (TP), and Fecal Coliforms (FC). Irrigation was carried out continuously during $24 \mathrm{~h}$. During irrigation, $\mathrm{pH}$ and Electrical Conductivity (EC) was measured in the stored water on days 0,3 , and 7 in each EU. After $7 \mathrm{~d}$, the remaining water was assessed in terms of volume and discarded. The Temperature (T) and Relative Humidity $(\mathrm{RH})$ were gathered from the "Diego Aracena" Weather Station at the Iquique airport (Northern Chile) [27].

\section{Analytical Methods}

Samples were filtered $(0.45 \mu \mathrm{m})$ for the COD, TSS, TN, and TP readings. COD, TN and TP were measured photometrically (Hanna photometer model HI-83214) using the kits: a) COD, HI 93754B-25; b) TN, HI 93767A-50; and c) TP, HI 93763B-50 (analytical methods of adaptations of APHA-AWWA-WEF [28]). The TSS were determined according to APHA-AWWA-WEF [17]. Fecal Coliforms (FC) were determined by multiple tube fermentation [29]. The $\mathrm{pH}$ and Electrical Conductivity (EC) were measured with a Hanna portable multiparameter probe model HI-9829. Water volumes were measured with a test tube. Height was measured with a measuring tape and diameter was measured with a manual caliper.

\section{Statistical Analysis}

Statistical tests were used to evaluate the differences between: a) development of the plant, comparison between the height and diameter of the stem taking into account the values at the time of harvest, b) variations in $\mathrm{pH}$ and EC in the water used for EU-1 and EU-2 on day 0 , and c) variations in $\mathrm{pH}$ and $\mathrm{EC}$ during irrigation, comparing between days 0,3 , and 7 . The Wilcoxon test was used for the comparisons of numerals a and b. The Kruskal Wallis test was used for the comparison of numeral c. All statistical analyzes were carried out using the Infostat software with a significance level $\alpha=0.05$ [30].

\section{Results}

\section{Quality of the Effluent Water from the CWs and Used for Irrigation}

Table 1 presents the quality values of the effluent water from the CWs used as irrigation water, along with the limits of the standards included in the reuse guides. In this regard, COD (> $170 \mathrm{mg} / \mathrm{L})$ is the water quality parameter that presented the greatest difference 
when compared to the standards in table 1 . The TSS, the TN and the TP showed values within the standards in table 1, but they would have restrictions regarding crop and soil type [31]. Therefore, the CWs proposed in Vera et al. [26] would not be sufficient by themselves to achieve the reuse standards in table 1, therefore, more stages of treatment or recirculation must be integrated as it has already been done by other authors in CWs systems to treat wastewater under arid conditions [10], [32]. In addition, it is necessary to integrate some subsequent disinfection process into the proposed CWs systems for FC to reach the standards in table 1. Finally, regarding the nutritional requirements of Lilium regarding the macronutrients nitrogen and phosphorus, this is a plant that does not require large amounts of phosphorus, so the concentration reported in table 1 would be sufficient for its development [33]. Regarding nitrogen, Vera-Puerto et al. [5] indicated that the relationship between the forms of TN present in the treated wastewater (ammonium and nitrate) would not have adverse effects on the development of Lilium.

Table 1. Characteristics of the water used for irrigation and guideline values for reuse

\begin{tabular}{cccc}
\hline Parameter & EU-1 & EU-2 & $\begin{array}{c}\text { Guideline values for } \\
\text { reuse }^{\mathbf{b}}\end{array}$ \\
\hline DQO (mg/L) & $\begin{array}{c}216.5 \pm 47.7 \\
(140-254)^{\mathrm{a}}\end{array}$ & $\begin{array}{c}178.0 \pm 35.6 \\
(131-218)\end{array}$ & $<100$ \\
\hline \multirow{2}{*}{ SST (mg/L) } & $\begin{array}{c}58.9 \pm 16.0 \\
(32-73)\end{array}$ & $\begin{array}{c}68.1 \pm 36.3 \\
(36-130)\end{array}$ & $<10-<60$ \\
\hline \multirow{2}{*}{ NT (mg/L) } & $\begin{array}{c}57.2 \pm 9.0 \\
(45-66.6)\end{array}$ & $\begin{array}{c}23.7 \pm 6.6 \\
(15-32)\end{array}$ & $<5-<125$ \\
\hline \multirow{2}{*}{ PT (mg/L) } & $\begin{array}{c}5.4 \pm 1.7 \\
(7.8-7.3)\end{array}$ & $\begin{array}{c}2.3 \pm 0.7 \\
(1.2-3.1)\end{array}$ & $<0.05-<12$ \\
\hline \multirow{2}{*}{ CF (Uni-Log) } & $\begin{array}{c}4.6 \pm 0.5 \\
(4.1-5.0)\end{array}$ & $\begin{array}{c}4.2 \pm 0.8 \\
(3.3-4.8)\end{array}$ & $<2-<4$ \\
\hline
\end{tabular}

$\mathrm{n}=5$ for DQO, SST, NT and PT; $\mathrm{n}=3$ for CF ${ }^{\mathrm{a}}$ (Min.-Max.).

Source: own source based on ${ }^{\text {b }}$ Lavrnić et al. [31]; Norton-Brandao et al. [34] and Vera-Puerto et al. [5].

Table 2 presents the variation of $\mathrm{pH}$ and $\mathrm{EC}$ on days 0,3 , and 7 in the irrigation water of each experimental unit (EU-1, EU-2). For day 0, the $\mathrm{pH}$ and EC show significant differences $(\mathrm{p}<0.05)$ between the EU-1 and EU-2. In addition, an increase in $\mathrm{pH}$ is observed as of day 3, up to 0.75 units in the mean values of EU-1 and up to 1.7 units in the mean values of EU-2. These increases would be significant $(p<0.05)$ in regard to each other, but do not affect its quality as irrigation water. This is because the recommended $\mathrm{pH}$ for irrigation water by different regulations can vary between 6.0 and 8.0, and even in guidelines for the reuse of treated water, it can go up to 9.5 [34]. On the other hand, the values for EC of EU-1 and EU-2 do not show significant reductions or increases ( $p>0.05)$, during the 7 days in which the water was used for irrigation. In this regard, the EU-1 EC 
values varied between 1500 and $3000 \mu \mathrm{s} / \mathrm{cm}$, which is why it is classified as "water with an adverse effect on most crops" [4]. On the other hand, the EC values in EU-2 were in the range of 3000 to $7500 \mu \mathrm{s} / \mathrm{cm}$, so it is classified as "water for crops tolerant to salinity only" [4]. Given these salinity conditions (as assessed according to EC), it is expected that there will be an influence on the development of the crops of the cut flower Lilium 'Tresor' used in this work.

Table 2. Evolution of the $\mathrm{pH}$ and EC for the water used in irrigation $(\mathrm{n}=9)$

\begin{tabular}{|c|c|c|c|}
\hline \multirow{2}{*}{ Day } & \multirow{2}{*}{$\begin{array}{l}\text { Experimental } \\
\text { Unit }\end{array}$} & \multicolumn{2}{|c|}{ Parameter } \\
\hline & & pH (Uni) & $\mathrm{EC}(\mu \mathrm{S} / \mathrm{cm})$ \\
\hline \multirow{2}{*}{0} & UE-1 & $7.5 \pm 0.1$ & $2359 \pm 62$ \\
\hline & UE-2 & $6.9 \pm 0.1$ & $3482 \pm 437$ \\
\hline \multirow{2}{*}{3} & UE-1 & $8.0 \pm 0.2$ & $2388 \pm 370$ \\
\hline & UE-2 & $8.7 \pm 0.1$ & $3204 \pm 462$ \\
\hline \multirow{2}{*}{7} & UE-1 & $8.3 \pm 0.4$ & $2422 \pm 300$ \\
\hline & UE-2 & $8.6 \pm 0.1$ & $3358 \pm 552$ \\
\hline
\end{tabular}

Source: Vera-Puerto et al. [5].

\section{Incidence of Environmental Factors}

During planting, the temperature showed average values between $14{ }^{\circ} \mathrm{C}$ and $16{ }^{\circ} \mathrm{C}$, with minimums above $12{ }^{\circ} \mathrm{C}$ and maximums below $20{ }^{\circ} \mathrm{C}$. In this regard, the ideal temperature for growing Lilium should have a minimum value of $8{ }^{\circ} \mathrm{C}$ to $10^{\circ} \mathrm{C}$ and a maximum value of $23{ }^{\circ} \mathrm{C}$ to $25^{\circ} \mathrm{C}$ [33]. Therefore, the temperature conditions during the planting time were adequate for the development of this crop. Regarding relative humidity, it varied between $55 \%$ and $85 \%$. The optimal relative humidity for Lilium should be between $80 \%$ and $85 \%$ [35]. However, other cut flowers such as roses have not shown issues with a relative humidity as low as $70 \%$ [36]. This would indicate that the relative humidity during planting would not affect the quality of the flower. On the other hand, Olave et al. [28] showed that the light intensity (luminosity variable) must be controlled to improve the height of the cut flowers cultivated in the Atacama Desert. The reason behind this is that under the arid conditions of this desert, light intensity can exceed 120 klux [23]. However, in this study, luminosity was not controlled, therefore, it is considered as one of the factors that affected the final height reached by the Lilium 'Tresor' flowers grown in this work.

\section{Development of the Cut Flower Crops}

Figure 2 presents the average growth per week for EU-1 and EU-2. The average height at harvest (week 9) varied by less than $0.1 \mathrm{~m}$ between the two experimental units, with a higher development in EU-1, but this difference was not significant ( $p>0.05$ ) when 
compared with EU-2. Height is defined as one of the most important indicators of commercial quality for this cut flower [37]. Values higher than $0.65 \mathrm{~m}$ are considered for export, but lower values are considered for national markets. Thus, the heights obtained in this work, between $0.5 \mathrm{~m}$ and $0.6 \mathrm{~m}$, would indicate that the flowers produced can be sold only in the national market [37]. Furthermore, these values for height are similar to those achieved by Schiappacasse et al. [38], who noted heights of $0.59 \mathrm{~m}$ for Lilium 'Dreamland' and 'Alhambra' in controls without shading. Regarding stem diameter, EU-1 and EU-2 were similar, with average values between $0.6 \mathrm{~cm}$ and $0.7 \mathrm{~cm}$, similar to those reported by Schiappacasse et al. [38].

Figure 2. Average growth of the plants per week (a) EU-1 (b) EU-2
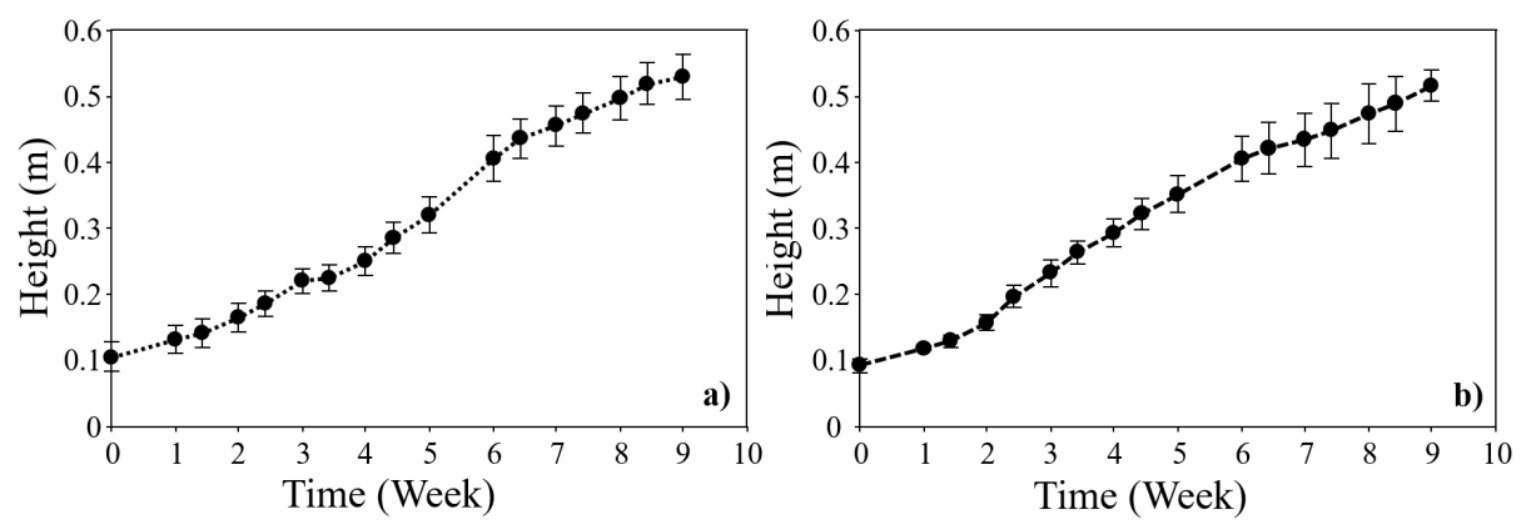

Source: Vera-Puerto et al. [5].

\section{Crop Water Efficiency}

Between 1.71 L (EU-1) and 2.35 L (EU-2) of water are required to produce a cut flower of Lilium 'Tresor' under the study conditions described in this work. These values are more than $50 \%$ higher than those reported by Safi et al. [21], who, when reusing effluents, reported water consumption values between $0.70 \mathrm{~L}$ and $1.11 \mathrm{~L}$ for a soilless cultivation system managed under arid conditions. The difference between this work and the one developed by Safi et al. [21] could be explained by the salinity of the water and the irrigation mode. Safi et al. [21] reported an EC of $2002 \mu \mathrm{s} / \mathrm{cm}$, while the EC was above $2300 \mu \mathrm{s} / \mathrm{cm}$ for the water in this study. Furthermore, Safi et al. [21] reported that programmed irrigation was used in their work, while continuous irrigation was carried out in this work. Despite this, other authors such as the International Flower Bulb Centre (IFBC) [35] indicate that for dry conditions (similar to arid conditions), water consumption can be as high as $9 \mathrm{~L} / \mathrm{m} 2$-d, which means that up to $0.163 \mathrm{~L} / \mathrm{unit}$ are required on a daily basis. Therefore, taking into consideration a cultivation time of $65 \mathrm{~d}$, the water required to 
produce a Lilium flower would be $10.6 \mathrm{~L}$. This would indicate that the water used to produce a Lilium flower in this work corresponds to only a $20 \%$ of the value indicated by the IFBC [35], thereby showing the potential advantage of the aeroponic cultivation system in terms of water usage. This would be consistent with the result of Treftz and Omaye [39], who found a reduction of up to $90 \%$ in the use of water for aeroponic lettuce crops when compared to conventional cultivation techniques. Despite this, the results of this work will require further scaling and optimization of irrigation to be more conclusive on the subject.

\section{Conclusions}

The cut flower, Lilium 'Tresor', was cultivated using an aeroponic cultivation system under the arid climatic conditions of the Atacama Desert, using municipal wastewater treated with constructed wetland systems for irrigation. This could be achieved despite issues with the water quality not adjusting to international guidelines; more stages of treatment are recommended to be added, particularly disinfection. However, the quality of the cut flower produced, as measured by its height of less than $0.65 \mathrm{~m}$, showed that it could only be sold in national markets. Among the factors that explain this commercial quality were the electrical conductivity of the irrigation water and the light intensity of the Atacama Desert. Finally, the aeroponic cultivation system showed to be efficient in the use of water, given that it used only $20 \%$ of the water that would be normally used when compared to other traditional cultivation techniques. Despite the above, for industrial scaling it would be necessary to control the light intensity — shading would be a recommended technique - as well as reducing the electrical conductivity in the effluents to be reused, where the mixing of the effluents with other sources of water with lower electrical conductivity would be recommended, while also considering the technical feasibility of using membrane desalination processes. Finally, it is recommended to optimize the irrigation process, using irrigation cycles taking into account the needs of the crop.

\section{Acknowledgements}

This work was funded by CONICYT/REGIONAL/CIDERH/R09I1001. The authors would like to thank Sergio Fuentes, Renzo Aravena, and Isabel de Tello from Aguas del Altiplano; Christian Santander, Mauricio Rojas, Camila Jorquera, and Nathaly Verdejo, from the Arturo Prat University; Luis Rojas of the Catholic University of Maule, and the CONICYT PCI/Attraction of Advanced Human Capital from Abroad/MEC80170068 project for the support to work on this manuscript with Dr. Carlos Arias. Finally, Ismael Vera-Puerto would like to thank the internal Project 434212 of the VRIP-Universidad Católica del Maule for supporting their research in wastewater treatment. 


\section{References}

[1] N. Hammouri, J. Adamowski, M. Freiwan, and S. Prasher, "Climate change impacts on surface water resources in arid and semi-arid regions: A case study in northern Jordan," Acta Geod. Geophys., vol. 52, no. 1, pp. 141-156, Mar. 2017. doi: 10.1007/s40328-016-0163-7

[2] L. Cáceres, J. Delatorre, F. de la Riva, and V. Monardes, "Greening of arid cities by residual water reuse: A multidisciplinary project in northern Chile," Ambio, vol. 32, no. 4, pp. 264-268, Jun. 2003. doi: 10.1639/0044-7447(2003)032[0264:GOACBR]2.0.CO;2

[3] C.-A. Villamar, I. Vera-Puerto, D. Rivera, and F. de la Hoz, "Reuse and recycling of livestock and municipal wastewater in Chilean agriculture: A preliminary assessment," Water, vol. 10, no. 6, p. 817, Jun. 2018. doi.org/10.3390/w10060817

[4] I. Vera, C. Jorquera, D. López, and G. Vidal, "Humedales construidos para tratamiento y reúso de aguas servidas en Chile : reflexiones," Tecnol. Cienc. Agua, vol. 7, no. 3, pp. 19-35, May./Jun. 2016. Available: http://www.scielo.org.mx/scielo.php?script=sci_arttext\&pid=S2007-24222016000300019

[5] I. Vera-Puerto, J. Olave, S. Tapia, and W. Chávez, "Atacama Desert: Water resources and reuse of municipal wastewater in irrigation of cut flower aeroponic cultivation system (first laboratory experiments)," Desalin. Water Treat., vol. 150, pp. 73-83, May 2019. doi: 10.5004/dwt.2019.23612

[6] B. Jiménez, "Irrigation in developing countries using wastewater," Int. Rev. Environ. Strateg., vol. 6, no. 2, pp. 229-250, Mar. $2006 . \quad$ Available: https://www.iges.or.jp/en/publication_documents/pub/peer/en/1199/IRES_Vol.6-2_229.pdf

[7] Y. Tapia et al., "Atriplex atacamensis and Atriplex halimus resist as contamination in Pre-Andean soils (northern Chile)," Sci. Total Environ., vol. 450-451, pp. 188-196, Apr. 2013. doi: 10.1016/j.scitotenv.2013.02.021

[8] A. Noyola, A. Padilla-Rivera, J. M. Morgan-Sagastume, L. P. Güereca, and F. Hernández-Padilla, "Typology of municipal wastewater treatment technologies in Latin America," CLEAN Soil, Air, Water, vol. 40, no. 9, pp. 926-932, Sep. 2012. doi: 10.1002/clen.201100707

[9] D. Zhang, K. Jinadasa, R. Gersberg, Y. Liu, W. Ng, and S. Tan, "Application of constructed wetlands for wastewater treatment in developing countries: A review of recent developments (20002013)," J. Environ. Manage., vol. 141, pp. 116-131, Aug. 2014. Available: https://doi.org/10.1016/j.jenvman.2014.03.015

[10] A. Albalawneh, T.-K. Chang, C.-S. Chou, and S. Naoum, "Efficiency of a horizontal sub-surface flow constructed wetland treatment system in an arid area," Water, vol. 8, no. 2, pp. 1-14, Feb. 2016. doi: $10.3390 / \mathrm{w} 8020051$

[11] A. Gross, O. Shmueli, Z. Ronen, and E. Raveh, "Recycled vertical flow constructed wetland (RVFCW): A novel method of recycling greywater for irrigation in small communities and households," Chemosphere, vol. 66, pp. 916-923, Jan. 2007. doi: 10.1016/j.chemosphere.2006.06.006

[12] K. Andersson et al., "Sanitation, wastewater management and sustainability: From waste disposal to resource recovery," UN Environment Programme and Stockholm Environment Institute, Nairobi, Kenya, 2016. [Online]. Available: https://www.sei.org/publications/sanitation-wastewater-andsustainability/

[13] F. Masi, A. Rizzo, and M. Regelsberger, "The role of constructed wetlands in a new circular economy, resource oriented, and ecosystem services paradigm," J. Environ. Manage., vol. 216, pp. 275-284, Jun. 2018. doi: 10.1016/j.jenvman.2017.11.086

[14] V. Burgos, F. Araya, C. Reyes-Contreras, I. Vera, and G. Vidal, "Performance of ornamental plants in mesocosm subsurface constructed wetlands under different organic sewage loading," Ecol. Eng., vol. 99, pp. 246-255, Feb. 2017. doi: 10.1016/j.ecoleng.2016.11.058

[15] L. Sandoval-Herazo, A. Alvarado-Lassman, J. Marín-Muñiz, J. Méndez-Contreras, and S. ZamoraCastro, "Effects of the use of ornamental plants and different substrates in the removal of wastewater pollutants through microcosms of constructed wetlands," Sustainability, vol. 10, no. 5, pp. 1594, May 2018. doi: 10.3390/su10051594

[16] S. Zamora-Castro, J. Marín-Muñiz, L. Sandoval, M. Vidal-Álvarez, and J. Carrión-Delgado, "Effect of ornamental plants, seasonality, and filter media material in fill-and-drain constructed wetlands treating rural community wastewater," Sustainability, vol. 11, no. 8, pp. 2350, Apr. 2019. doi: $10.3390 / \mathrm{su} 11082350$ 
[17] L. Sandoval, S. Zamora-Castro, M. Vidal-Álvarez, and J. Marín-Muñiz, "Role of wetland plants and use of ornamental flowering plants in constructed wetlands for wastewater treatment: A review," Appl. Sci., vol. 9, no. 4, pp. 685, Feb. 2019. doi: 10.3390/app9040685

[18] J. Travis, N. Weisbrod, and A. Gross, "Decentralized wetland-based treatment of oil-rich farm wastewater for reuse in an arid environment," Ecol. Eng., vol. 39, pp. 81-89, Feb. 2012. doi: 10.1016/j.ecoleng.2011.11.008

[19] S. Abou-Elela, G. Golinelli, A. Saad El-Tabl, and M. Hellal, "Treatment of municipal wastewater using horizontal flow constructed wetlands in Egypt," Water Sci. Technol., vol. 69, no. 1, pp. 38-47, Jan. 2014. doi: 10.2166/wst.2013.530

[20] L. Latrach, N. Ouazzani, A. Hejjaj, M. Mahi, T. Masunaga, and L. Mandi, "Two-stage vertical flow multi-soil-layering (MSL) technology for efficient removal of coliforms and human pathogens from domestic wastewater in rural areas under arid climate," Int. J. Hyg. Environ. Health, vol. 221, no. 1, pp. 64-80, Jan. 2018. doi: 10.1016/j.ijheh.2017.10.004

[21] M. Safi, A. Bulad, A. Blawenah, and I. Bashabsheh, "Water use efficiency, flower yield and quality of 'Lilium aziatische' irrigated with different water types," Int. J. Agric. Biol., vol. 9, no. 2, pp. 264266, Jul. 2007. Available: http://www.fspublishers.org/published_papers/44488_..pdf

[22] A. Alderfasi, "Agronomic and economic benefits of reuse secondary treated wastewater in irrigation under arid and semi-arid region," World J. Agric. Sci., vol. 5, no. 3, pp. 369-374, Jan. 2009. Available:

https://www.researchgate.net/publication/237501488_Agronomic_and_Economic_Impacts_of_Reus e_Secondary_Treated_Wastewater_in_Irrigation_under_Arid_and_Semi-Arid_Regions

[23] J. Olave, B. Torres, W. Chávez, and O. González, Producción de Lilium bajo invernadero en un sistema aeropónico recirculante con agua residual urbana tratada en el desierto de Atacama. Iquique: Universidad Arturo Prat, Fundación para la Innovación Agraria (FIA), 2016.

[24] C. Cassaniti, D. Romano, and T. Flowers, "The response of ornamental plants to saline irrigation water," in Irrigation: Water Management, Pollution and Alternative Strategies, I. García-Garizabal, Ed. Rijeka: IntechOpen, 2012, pp. 131-158.

[25] K. Al-Ghawanmeh, N. Bani Hani, A. Al-Hammouri, and N. Karam, "Effect of irrigation with nutrient solutions mixed with treated wastewater on Asiatic lily 'Brunello' grown in a closed soilless culture,” Acta Agric. Slov., vol. 109, no. 1, pp. 29-42, Jan. 2017. doi: 10.14720/aas.2017.109.1.03

[26] I. Vera, N. Verdejo, W. Chávez, C. Jorquera, and J. Olave, "Influence of hydraulic retention time and plant species on performance of mesocosm subsurface constructed wetlands during municipal wastewater treatment in super-arid areas," J. Environ. Sci. Heal. Part A, vol. 51, no. 2, pp. 105-113, Jan. 2016. doi: 10.1080/10934529.2015.1087732

[27] Dirección Meteorológica de Chile, "Productos climatológicos actuales e históricos: Estación Diego Aracena," $2014 . \quad$ [Online]. Available: https://climatologia.meteochile.gob.cl/application/informacion/fichaDeEstacion/200006\#inventario

[28] American Public Health Association, American Water Works Association, and Water Environment Federation, Standard Methods for the Examination of Water and Wastewater, 20th Ed. Washington: APHA American Public Health Association, 1998.

[29] NCh 2313/23 of. 95 Aguas Residuales Métodos de Análisis Parte 23: Determinación de Coliformes Fecales en medio A-1, 1995.

[30] J. di Rienzo, F. Casanoves, M. Balzarini, L. Gonzalez, M. Tablada, and C. Robledo, "InfoStat Versión 2018," Grupo InfoStat, FCA, Universidad Nacional de Córdoba, Argentina, 2018. Available: http://www.infostat.com.ar

[31] S. Lavrnić, M. Zapater-Pereyra, and M. L. Mancini, "Water scarcity and wastewater reuse standards in Southern Europe: Focus on agriculture," Water, Air, Soil Pollut., vol. 228, no. 7, pp. 2-12, Jul. 2017. doi: 10.1007/s11270-017-3425-2

[32] Y. Tencer, G. Idan, M. Strom, and U. Nusinow, "Establishment of a constructed wetland in extreme dryland," Environ. Sci. Pollut. Res., vol. 16, no. 7, pp. 862-875, Nov. 2009. doi: 10.1007/s11356009-0232-3

[33] G. Verdugo et al., Producción de flores cortadas: V Región. Santiago, Chile: Fundacción para la Innovación Agraria (FIA), Instituto de Investigaciones Agropecuarias (INIA), 2007. [Online]. Available:

http://bibliotecadigital.fia.cl/bitstream/handle/20.500.11944/1851/3FloresVReg.pdf?sequence=1\&is Allowed $=\mathrm{y}$ 
[34] D. Norton-Brandão, S. Scherrenberg, and J. van Lier, "Reclamation of used urban waters for irrigation purposes: A review of treatment technologies," J. Environ. Manage., vol. 122, pp. 85-98, Jun. 2013. doi: 10.1016/j.jenvman.2013.03.012

[35] Centro Internacional de Bulbos de Flor (CIBF), El cultivo del lilium: flor cortada y cultivo en maceta. Hillegom: Centro Internacional de Bulbos de Flor, 1980.

[36] B.-C. In and J. H. Lim, "Potential vase life of cut roses: Seasonal variation and relationships with growth conditions, phenotypes, and gene expressions," Postharvest Biol. Technol., vol. 135, pp. 93 103, Jan. 2018. doi: 10.1016/j.postharvbio.2017.09.006

[37] O. Auzaque-Rodríguez, H. Balaguera-López, J. Álvarez-Herrera, and G. Fischer, "Efecto de la vernalización de bulbos reutilizados sobre la calidad de la flor de lirio (Lilium sp.) en la Sabana de Bogotá," Agron. Colomb., vol. 27, no. 1, pp. 65-71, Jan. 2009. Available: https://www.researchgate.net/publication/256473694_Efecto_de_la_vernalizacion_de_bulbos_reutili zados_sobre_la_calidad_de_la_flor_de_lirio_Lilium_sp_en_la_Sabana_de_Bogota

[38] F. Schiappacasse, G. Carrasco, and F. Carrasco, "Effect of four shading levels on flower stem and bulb quality of two lilies (Lilium spp.) cultivars (In Spanish)," Agric. Técnica, vol. 66, no. 4, pp. 352-359, Oct. 2006. Available: http://dx.doi.org/10.4067/S0365-28072006000400003

[39] C. Treftz and S. Omaye, "Hydroponics: Potential for augmenting sustainable food production in nonarable regions," Nutr. Food Sci., vol. 46, no. 5, pp. 672-684, Sep. 2016. doi: 10.1108/NFS-10-20150118 